\title{
Fusarium species and Fusarium mycotoxins in grain of wheat in Poland in 2009 and 2010
}

\author{
Tomasz Góral' ${ }^{1}$, Piotr Ochodzki ${ }^{1}$, Linda K. Nielsen², Dorota Walentyn-Góral ${ }^{1}$ \\ ${ }^{1}$ Department of Plant Pathology, Plant Breeding and Acclimatization Institute - National \\ Research Institute, Radzików, 05-870 Błonie, Poland; t.goral@ihar.edu.pl; \\ ${ }^{2}$ Sejet Plant Breeding, Nørremarksvej 67, 8700 Horsens, Denmark
}

\begin{abstract}
The aim of the study was to determine the presence Fusarium species and mycotoxins in winter wheat grain in Poland. Grain samples from different locations in Poland in 2009 and 2010 were analysed for the content of biomass of Fusarium species and mycotoxins. In 2009 biomass of $F$. graminearum and $F$. poae was present in all samples, $F$. culmorum in $82 \%$ of samples, $F$. avenaceum in $55 \%$ of samples. $F$. sporotrichioides, $F$. tricinctum and $F$. equiseti were found only in individual samples. F. langsethiae was not detected. In 2010, five Fusarium species were detected with the exception of $F$. sporotrichioides. The highest content of biomass was found for $F$. graminearum followed by $F$. avenaceum, $F$. poae and $F$. langsethiae. The amount of $F$. culmorum biomass was very low. The most frequently occurring species was $F$. poae and $F$. graminearum. In 2009, deoxynivalenol was detected in all samples. In 2010, the average content of deoxynivalenol was lower than in 2009. Nivalenol was detected at very low concentration in both years. Significant correlations between content of $F$. graminearum biomass and deoxynivalenol concentration in grain and between content of $F$. poae biomass and nivalenol concentration in grain in 2009 were found. The most important finding of this study was that main Fusarium species infecting wheat kernels in Poland in both years was $F$. graminearum. The amount of biomass of $F$. graminearum was the highest in both years. It was present in the most samples. The other frequently detected species was $F$. poae, which in 2010 appeared in more samples than $F$. graminearum. However, the amount of $F$. poae biomass was lower. F. culmorum, species that was previously dominating as wheat pathogen in Poland, was found less frequently than $F$. graminearum. The amount of biomass of this species was the lowest in 2010.
\end{abstract}

Key words: biomass, Fusarium head blight, real-time PCR, trichothecenes, zearalenone

\section{Introduction}

Fusarium head blight (FHB) is a disease of wheat caused by a complex of toxicogenic fungi of the genus Fusarium (Parry et al., 1995). The main species of this complex in Europe are $F$. graminearum and $F$. culmorum identified as deoxynivalenol (DON), nivalenol (NIV) and zearalenone (ZEN) producers. However, other Fusarium species producing mycotoxins are also prevalent: F. avenaceum - moniliformin, enniatins and beauvericin (BEA) producer, $F$. poae NIV, BEA producer. Fusarium langsethiae and F. sporotrichioides - T-2 and HT-2 toxins producers are also prevalent (Bottalico, 1998; Bottalico and Perrone, 2002; Jestoi et al., 2008; Somma et al., 2010; Vogelgsang et al., 2008). Fusarium graminearum and $F$. culmorum are highly pathogenic species, which can cause severe epidemics of Fusarium head blight. The other species are medium or weakly pathogenic, however, due to the wide prevalence, these may also cause mycotoxin contamination of grain (Nielsen et al., 2011; Uhlig et al., 2007; YliMattila et al., 2004, 2008). Because of the diversity of Fusarium species causing Fusarium head blight, monitoring of changes in the Fusarium population on wheat is important. Frequency of 
species infecting wheat is not stable and changes depending on weather in particular year. Large differences are also observed between different regions of wheat productions in Europe. For example, the other species dominate in north-eastern Europe then in south-western part of the continent (Bottalico, 1998; Bottalico and Perrone, 2002). Species compositions changes over time, which is the results of climate warming, and changes in acreage of major cereal crops increase of maize area. The main reported effect of the above factors is increase of $F$. graminearum and decrease of F. culmorum (Miller, 2008; Parikka et al., 2012; Scherm et al., 2013). Chandelier et al. (2011) analysed winter wheat samples from Belgium over 2003-2009 period. They found that main species were $F$. avenaceum and $F$. graminearum; however, their frequency changed depending on year from 20 to $100 \%$. The frequency of $F$. poae was relatively constant over the years (about 70\%). The overall incidence of $F$. culmorum decreased during the study, from $80 \%$ in 2003 to $10 \%$ over the final three years. Similarly, Isebaert et al. (2009) observed that $F$. graminearum and $F$. culmorum were the most importnat species in northern Belgium in 2002-2005. They found interesiting correlation between crops and both species frequency (maize $-F$. graminearum, small grain cereals $-F$. culmorum). In Luxemburg, the most common species isolated from wheat heads were $F$. graminearum, $F$. avenaceum and $F$. poae. Increase of frequency of $F$. graminearum and decrease in $F$. culmorum were observed (Giraud et al., 2010). Winter wheat cultivated in the Netherlands in 2009 was studied for Fusarium species and toxins (van der Fels-Klerx et al., 2012). In samples collected on harvest, authors found dominance of $F$. graminearum. F. avenaceum and Microdochium nivale were also frequent. However, in the pre-harvest samples, only $F$. graminearum and $M$. nivale were present. Waalwijk et al. (2004) analysed wheat heads and grain collected in the Netherlands in 2001 and 2002. In 2001, in samples collected at late milk stage, $F$. graminearum was predominant; however, some samples contained also $F$. avenaceum and/or $F$. culmorum. At harvest, $F$. graminearum dominated almost completely. In 2002 the weather conditions were more favorable for FHB and they found relative dominance of $F$. graminearum in grain from the Netherlands and almost complete in samples from France. According to Birzele et al., (2002) in 1997 and 1998 the dominating species in Germany in wheat grain were F. avenaceum, $F$. poae, $F$. culmorum and $F$. graminearum. Frequencies of two last species were similar, however percentage of $F$. graminearum increased in 1998. In Germany in 2008, $F$. graminearum sensu stricto was the predominant species followed by $F$. culmorum. Other species (F. poae, F. tricinctum, M. nivale etc.) were identified in small amounts (Talas et al., 2011). In Hungary, in year 2010, which was very favorable for Fusarium head blight development, predominantly $F$. graminearum was isolated from wheat grain (Laszlo et al., 2011).

Waalwijk et al. (2003) analysed wheat spikes with Fusarium head blight symptoms collected in Netherlands in 2000 and 2001. They found that F. graminearum was the dominating Fusarium species in both years. As they stated, this was significant change comparing results from the 1980s and 1990s, which showed that F. culmorum was the predominant species in the Netherlands. They presume that this shift could be connected with an increase in maize acreage. $F$. graminearum, unlike $F$. culmorum, is a major pathogen on maize and, can survive on maize debris. The other factor could be climate warming which favours $F$. graminearum as it has higher optimal temperature of development. The prevalence of FHB pathogens differed significantly between studied countries in 2001 and 2002 (UK, Ireland, Italy and Hungary) (Xu et al., 2005). Overall, all pathogens ( $F$. graminearum, $F$. culmorum, $F$. avenaceum and $F$. poae) were commonly detected in Ireland and to a lesser extent in the UK. In contrast, only two species, $F$. graminearum and $F$. poae, were regularly detected in Italy and Hungary. Fusarium culmorum was rarely detected except in Ireland. The later country is has the coolest summer weather among four studied countries. Authors stated that the increase of $F$. graminearum, especially in the UK, appears to have been at the expense of $F$. culmorum. The replacement of 
$F$. culmorum by $F$. graminearum as the predominant FHB pathogen was also reported in Bavaria (Obst et al., 1997) where the change was linked with increased maize production. It is worth to notice that in Poland grain maize acreage increased considerably from 1990 (59000 ha) to 2017 (above $1215500 \mathrm{ha}$ ).

The Fusarium species can be isolated from cereal kernels and identified using classical and/or molecular methods (Wiśniewska et al., 2014). The molecular method widely used for identification and quantification of Fusarium biomass concentration in samples is real time PCR (Horevaj et al., 2011; Nicolaisen et al., 2009; Nielsen et al., 2011, 2013; Niessen, 2007). The aim of the present study was to determine the presence Fusarium species and content of mycotoxins in wheat grain in Poland to compare species frequency with earlier reported data.

\section{Material and methods}

\section{Cereal grain samples}

Fifty samples of wheat grain were collected during the harvesting season 2010 . They originated from 25 experimental stations of COBORU (the Research Centre for Cultivar Testing) located in different regions of Poland (Figure 1). Two winter wheat cultivars 'Bogatka' (medium resistant to FHB) and 'Muszelka' (susceptible) were included. The winter wheat was grown with a moderate nitrogen input (avg. $90 \mathrm{~kg} / \mathrm{ha}$ of $\mathrm{N}$ ) and without chemical control of diseases. The grain was harvested using combine harvester.

Additionally 18 samples of wheat grain from 2009 and 2010 were analysed. Samples were collected from different locations/fields and cultivars (Table 1, Figure 1). Collected samples were stored at $-20^{\circ} \mathrm{C}$ before DNA and mycotoxins extraction.

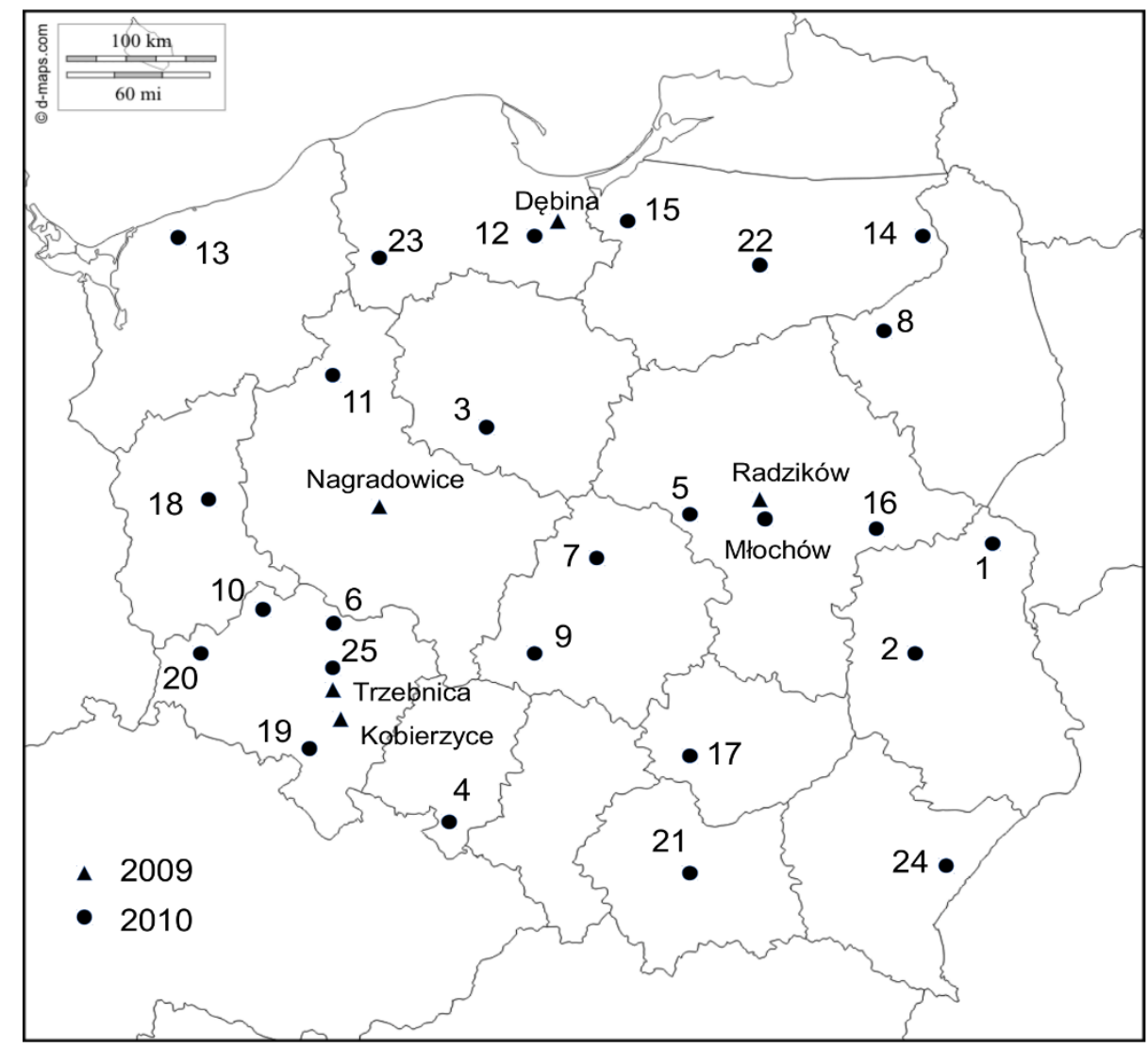

Figure 1. Map of Poland showing sample collection locations of winter and spring wheat in 2009 (triangles) and 2010 (circles). Location numbers correspond to these in Table 3 


\section{DNA extraction and analysis}

Grain samples of $300 \mathrm{~g}$ were initially grounded with a laboratory grinder and $5 \mathrm{~g}$ was powdered in liquid $\mathrm{N}_{2}$ with eight steel balls using Geno/Grinder 2000 (OPS Diagnostics, Bridgewater, NJ). DNA was extracted from $100 \mathrm{mg}$ of that powdered sample using a modified CTAB method (http://gmo-crl.jrc.ec.europa.eu/summaries/NK603-WEB-ProtocolValidation.pdf) as described by Nicolaisen et al. (2009). DNA extracted from the wheat samples was further purified using a DNeasy kit (Qiagen) according to the manufacturer's instructions.

The Fusarium isolates: F. avenaceum 9605, F. culmorum 9560, F. equiseti 8752, $F$. graminearum 1955, F. langsethiae $8051, F$. poae 8452, F. sporotrichioides 1926, and $F$. tricinctum 8048 were grown and extracted as described in Nielsen et al. (2011). They were grown on potato dextrose agar (PDA) medium at $22^{\circ} \mathrm{C}$ under $12 \mathrm{~h}$ of light and $12 \mathrm{~h}$ of darkness for 1-2 weeks prior to DNA extraction. PDA plates before inoculation were covered with sterile cellophane membranes (Horevaj et al., 2011). Mycelium was scraped off the cellophane membrane using a spatula and ground in liquid $\mathrm{N}_{2}$ with eight steel balls using a Geno/Grinder 2000 (OPS Diagnostics, Bridgewater, NJ). Powdered mycelium (100 mg) was used for DNA extraction, using the same method as for grain samples. The concentration of DNA from Fusarium isolates was determined using NanoDrop 1000 (Thermo Fisher Scientific, MA).

Qualitative and quantitative determinations of eight Fusarium species in grain were performed by real time-PCR. Primers used were based on fungal TEF- $1 \alpha$ gene sequences, designed by Nicolaisen et al. (2009), specific for the different Fusarium species: $F$. avenaceum, $F$. culmorum, F. equiseti, F. graminearum, F. langsethiae, $F$. poae, $F$. sporotrichioides, and $F$. tricinctum.

Real-time PCR was carried out in a total of $12.5 \mu$ l consisting of $6.25 \mu 1$ of $2 \times$ SYBR Green PCR Master Mix (Applied Biosystems), $250 \mathrm{nM}$ each primer, bovine serum albumin at 0.5 $\mu \mathrm{g} / \mu \mathrm{l}$, and $2.5 \mu \mathrm{l}$ of template DNA. PCR reactions were performed in duplicate on all samples. Genomic DNA from grain samples and pure cultures was diluted 1:10 before PCR.

PCR was performed on a 7900HT Sequence Detection System (Applied Biosystems) using the following cycling protocol: $2 \mathrm{~min}$ at $50^{\circ} \mathrm{C} ; 95^{\circ} \mathrm{C}$ for $10 \mathrm{~min} ; 40$ cycles of $95^{\circ} \mathrm{C}$ for $15 \mathrm{~s}$ and $62^{\circ} \mathrm{C}$ for $1 \mathrm{~min}$; followed by dissociation analysis at 60 to $95^{\circ} \mathrm{C}$. For the plant assay annealing and extension was performed at $60{ }^{\circ} \mathrm{C}$. Standard curves for Fusarium species and wheat were made of five-fold dilution series using pure fungal DNA and wheat DNA. The amount of fungal DNA was calculated from the cycle threshold $(\mathrm{Ct})$ values using the standard curve. The result of each individual sample from each species-specific assay were evaluated by studying the dissociation curve and Ct value, as SYBR Green binds to all double stranded DNA and might create false positives. The plant EF1 $\alpha$ assay was used to provide a normalized measurement for Fusarium biomass in each sample, which was calculated as picograms of fungal DNA per micrograms of plant DNA according to Nicolaisen et al. (2009).

\section{Analysis of Fusarium toxins}

The trichothecenes of group B - deoxynivalenol (DON), nivalenol (NIV) were quantified using gas chromatography techniques. Those mycotoxins were extracted from $5 \mathrm{~g}$ of ground grains using $25 \mathrm{ml}$ of an aqueous solution of acetonitrile (acetonitrile: water 84: 16) in a shaker overnight. Samples were centrifuged (3000 rpm min-1, $5 \mathrm{~min}$.), and the extract was purified with MycoSep® 227 Trich+ columns (Romer Labs Inc., Union, MO). One microliter of the internal standard solution (chloralose) was added to $4 \mathrm{ml}$ of purified extract. The solvent was evaporated to dryness in the air stream. Mycotoxins were drivatised to the trimethylsilyl derivatives using a derivatizing agent Sylon BTZ (BSA + TMCS + TMSI, 3: 2: 3, Supelco). After dissolution of sample in isooctane, excess of derivatizing agent was decomposed and 
removed with water. The organic layer was transferred to autosampler vial and analysed chromatographically with gas chromatograph SRI 8610C, with BGB-5MS column of $30 \mathrm{~m}$ in length, and an internal diameter of $0, .25 \mathrm{~mm}$.

Hydrogen was a carrier. Elution was carried out in the temperature gradient. Mycotoxin detection was carried out using electron capture detector (ECD). Identification of individual compounds was made by comparing the retention times of the pure standards of mycotoxins. The concentration of mycotoxins was established on the basis of the calibration curve, using chloralose as the internal standard.

The content of zearalenone (ZEN) was determined using a quantitative direct competitive enzyme-linked immunosorbent assay (ELISA) AgraQuant ${ }^{\circledR}$ ZON 40/1000 (LOD 10 ppb) (Romer Laboratories). In 2010, samples were analysed for T-2/HT-2 toxins using AgraQuant ${ }^{\circledR}$ T-2 Toxin 75/500 (LOD 35 ppb) assay (Romer Laboratories).

\section{Statistical analysis}

The original Fusarium biomass and toxin concentrations were transformed to logarithmic values in order to obtain a normal distribution for the variables. The relationships between the results for Fusarium biomass and Fusarium toxins were investigated by Pearson correlation tests. Principal component analysis was used to analyse concentration of biomass of Fusarium avenaceum, $F$. culmorum, $F$. graminearum, $F$. langsethiae and $F$. poae, and concentration of biomass of Fusarium culmorum, $F$. graminearum and $F$. poae, and concentration of Fusarium toxins (DON, NIV, ZEN) in 50 grain samples of winter wheat collected from 25 locations in Poland. Significance of differences between samples from different regions or samples for different Fusarium species was analysed using nonparametric tests (Kruskall-Wallis test, Mann-Whitney test). The correlation and PCA analyses were performed using Microsoft ${ }^{\circ}$ Excel 2010/XLSTAT@-Pro (Version 2013.4.07, Addinsoft, Inc., Brooklyn, NY, USA).

\section{Results}

In wheat samples from 2009 presence of Fusarium DNA was found. The highest amount of Fusarium biomass was found in grain of spring wheat 'Griwa' (Radzików 1) sown after maize and winter wheat 'Muszelka' (Dębina 2), which is highly susceptible to Fusarium head blight (Table 1). The lowest amounts were detected in grain of winter wheat cultivars 'Zawisza' (Radzików 5) and 'Tonacja' (Radzików 5) and in spring wheat 'Raweta' (Radzików 3).

Table 1. Concentration of Fusarium species biomass and DON, NIV and ZEN mycotoxins levels in samples of grain of spring and winter wheat collected in 2009

\begin{tabular}{|c|c|c|c|c|c|c|c|c|}
\hline \multirow{2}{*}{ No. } & \multirow{2}{*}{ Sample name } & \multicolumn{4}{|c|}{ 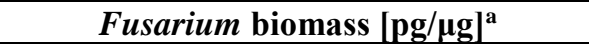 } & \multirow{2}{*}{$\begin{array}{c}\text { DON } \\
{[\mu \mathrm{g} / \mathrm{kg}]}\end{array}$} & \multirow{2}{*}{$\begin{array}{c}\text { NIV } \\
{[\mu \mathrm{g} / \mathrm{kg}]}\end{array}$} & \multirow{2}{*}{$\begin{array}{r}\text { ZEN } \\
{[\mu \mathrm{g} / \mathrm{kg}}\end{array}$} \\
\hline & & $F a$ & $F_{C}$ & $F g$ & $F p$ & & & \\
\hline 1 & Radzików $1^{b}$ & 1300 & 153 & 60248 & 70 & 5719 & 43 & 63 \\
\hline 2 & Radzików $2^{b}$ & 89 & 41 & 21804 & 0 & 2020 & 0 & 25 \\
\hline 3 & Radzików $3^{\mathrm{b}}$ & 53 & 31 & 911 & 9 & 104 & 0 & 0 \\
\hline 4 & Dębina 1 & 0 & 316 & 18966 & 63 & 2937 & 45 & 78 \\
\hline 5 & Dębina $2^{\mathrm{c}}$ & 533 & 8862 & 46102 & 287 & 7170 & 281 & 29 \\
\hline 6 & Kobierzyce & 0 & 387 & 26384 & 949 & $\mathrm{n} / \mathrm{a}$ & $\mathrm{n} / \mathrm{a}$ & $\mathrm{n} / \mathrm{a}$ \\
\hline 7 & Nagradowice ${ }^{c}$ & 366 & 22949 & 5462 & 67 & 9239 & 33 & 230 \\
\hline 8 & Radzików 4 & 0 & 34 & 4277 & 137 & 658 & 177 & 0 \\
\hline 9 & Radzików 5 & 63 & 38 & 2115 & 187 & 213 & 36 & 12 \\
\hline 10 & Radzików 6 & 0 & 0 & 207 & 33 & 47 & 0 & 17 \\
\hline 11 & Trzebnica & 1753 & 252 & 2044 & 285 & 123 & 61 & 0 \\
\hline & Mean & 378 & 3006 & 17138 & 190 & 2823 & 68 & 45 \\
\hline
\end{tabular}

$\overline{\mathrm{a}}-F$. langsethiae, F. sporotrichioides and F. langsethiae were excluded; ${ }^{\mathrm{b}}$ - spring wheat; ${ }^{\mathrm{c}}-$ grain from collected symptomatic spikes; $\mathrm{Fa}=F$. avenaceum, $\mathrm{Fc}=F$. culmorum, $\mathrm{Fg}=F$. graminearum, $\mathrm{Fp}=F$. poae 
Seven Fusarium species, except $F$. langsethiae, were detected in wheat grain. $F$. graminearum was present in all samples, $F$. poae and $F$. culmorum in ten samples $(91 \%), F$. avenaceum in seven samples (64\%). F. sporotrichioides and $F$. tricinctum were found in two individual samples. First species in sample 'Radzików 1' at $69 \mathrm{pg} / \mu \mathrm{g}$, and the second in wheat grain from Debina ('Dębina 2') at $428 \mathrm{pg} / \mu \mathrm{g}$. Traces of $F$. equiseti were found in two samples ('Debina 2', 'Nagradowice').

Despite large differences in Fusarium biomass content in grain samples, amount of $F$. graminearum DNA was the highest in eight samples (Figure 2). F. culmorum dominated only in a sample from Nagradowice and in sample from Trzebnica concentrations of $F$. avenaceum and $F$. graminearum biomasses were similar.

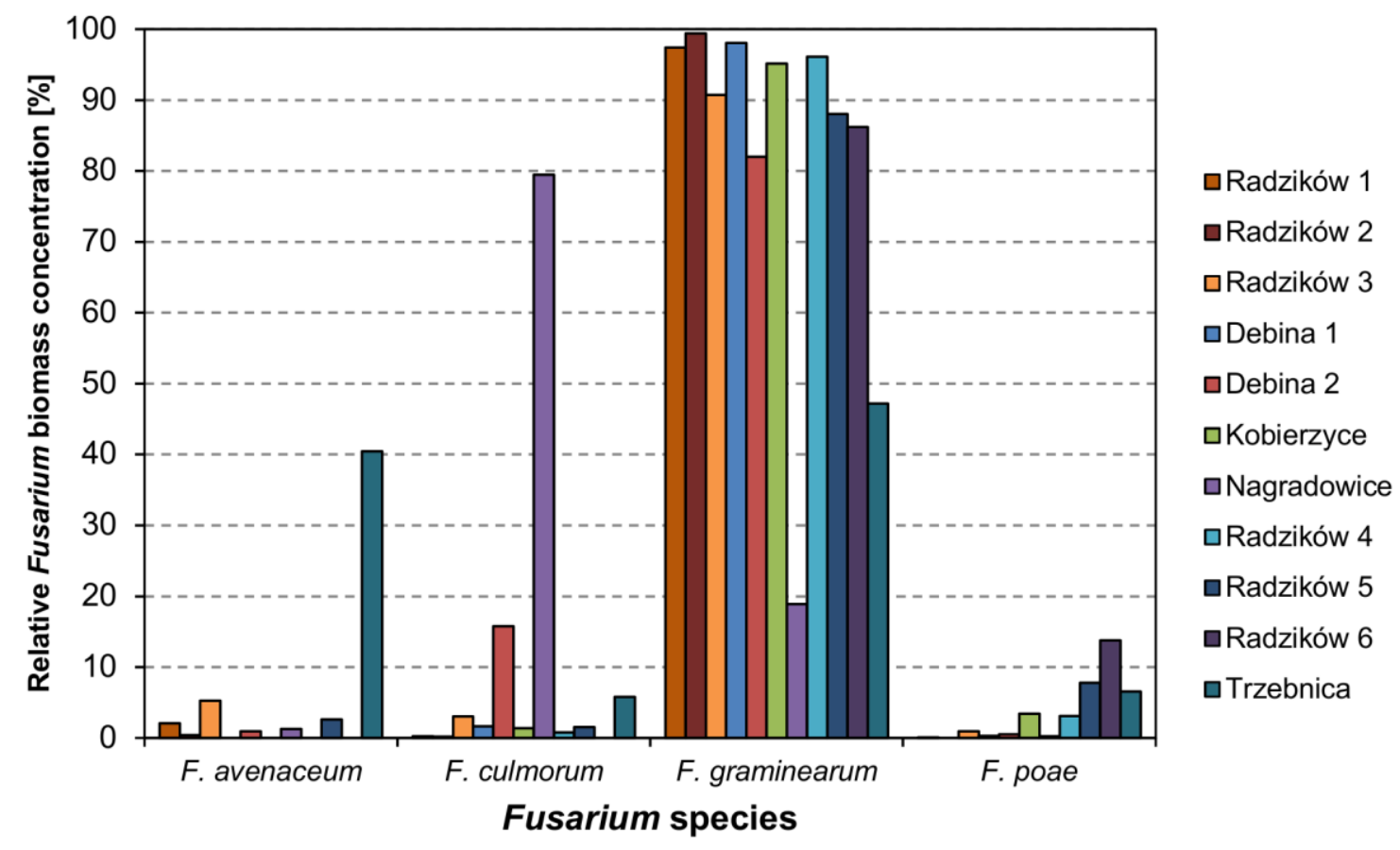

Figure 2. Relative concentration of biomasses of four Fusarium species in 11 samples of spring and winter wheat collected in 2009. F. equiseti, F. sporotrichioides and F. tricinctum were excluded

DON was detected in all samples at the average level of $2823 \mu \mathrm{g} / \mathrm{kg}$ (Table 1). The most contaminated were grain samples of winter wheat 'Nagradowice' and 'Debina 2' and spring wheat 'Radzików 1'. Levels of NIV were much lower. On average, it was $74 \mu \mathrm{g} / \mathrm{kg}$. NIV was detected in seven samples. The highest concentration was in grain of winter wheat from 'Debina 2' and winter wheat 'Radzików 4'. ZEN was detected in seven samples at the average level of $51 \mu \mathrm{g} / \mathrm{kg}$. Considerable amounts of ZEN were found in samples from Nagradowice and in samples of spring wheat 'Radzików 1' and winter wheat 'Dębinal'. DON concentration correlated significantly with total Fusarium biomass ( $\mathrm{r}=0.947)$, for NIV and ZEN coefficients were no significant $r=0.537$ and $r=0.561$, respectively (Table 2).

When looking at individual species, high correlation between DON and biomass of $F$. graminearum and $F$. culmorum were evident (Table 2). As regards NIV, significant correlation was observed with $F$. poae biomass.

In 2010 average concentration of Fusarium biomass was $1970 \mathrm{pg} / \mu \mathrm{g}(1430 \mathrm{pg} / \mu \mathrm{g}$ in 'Bogatka' grain and $3770 \mathrm{pg} / \mu \mathrm{g}$ in 'Muszelka' grain) (Table 3). The highest concentration of biomass was detected in grain from Zadąbrowie, South-Eastern Poland (Figure 1). The biomass was five-six times lower in grain from Czesławice (South-Eastern Poland), Rychliki, Radostowo (Northern P1.) and Głubczyce (Southern Pl.). Very low concentration of biomass was found in grain from 
Naroczyce, Nowa Wieś Ujska (western Poland), Kawęczyn (central Poland), and Rarwino (north-western Poland). At a regional scale the highest Fusarium biomass concentration was observed in grain from South-Eastern and North-Eastern Poland and the lowest concentrations was observed in grain from Western, north-western and central Poland (Figure 1). Concentration of Fusarium biomass was significantly higher in south-eastern region according to Kruskal-Wallis test.

Table 2. Coefficients of correlation between concentrations of biomass (pg/ $\mu \mathrm{g})$ of four Fusarium species and mycotoxins $(\mu \mathrm{g} / \mathrm{kg})$ DON, NIV and ZEN in grain of wheat collected in 2009.

\begin{tabular}{|c|c|c|c|c|c|c|c|}
\hline & \multicolumn{5}{|c|}{ Fusarium biomass } & \multicolumn{2}{|c|}{ Mycotoxin } \\
\hline & Fusarium & F.avenaceum & F. culmorum & F. graminearum & F.poae & DON & NIV \\
\hline F. avenaceum & 0.400 & & & & & & \\
\hline F. culmorum & 0.696 & 0.462 & & & & & \\
\hline $\begin{array}{l}F . \\
\text { graminearum }\end{array}$ & 0.960 & 0.273 & 0.508 & & & & \\
\hline F.poae & 0.266 & 0.043 & 0.370 & 0.243 & & & \\
\hline DON & 0.947 & - & 0.740 & 0.885 & 0.083 & & \\
\hline NIV & 0.537 & - & 0.557 & 0.491 & 0.875 & 0.477 & \\
\hline ZEN & 0.561 & - & 0.518 & 0.482 & - & 0.706 & 0.070 \\
\hline
\end{tabular}

All variables were log transformed. Values in bold are different from 0 with a significance level $\mathrm{P} \leq 0.05$

Table 3. Concentration of total Fusarium biomass, and DON, NIV and ZEN mycotoxins levels in grain of winter wheat cultivars 'Bogatka' and 'Muszelka' from 2010 harvest

\begin{tabular}{|c|c|c|c|c|c|c|c|c|c|}
\hline \multirow[t]{2}{*}{ No. } & \multirow[t]{2}{*}{ Location } & \multicolumn{2}{|c|}{$\begin{array}{c}\text { Fusarium biomass } \\
{[\mathrm{pg} / \mu \mathrm{g}]^{\mathrm{a}}}\end{array}$} & \multicolumn{2}{|c|}{$\begin{array}{c}\text { DON } \\
{[\mu g / k g]}\end{array}$} & \multicolumn{2}{|c|}{$\begin{array}{c}\text { NIV } \\
{[\mu \mathrm{g} / \mathrm{kg}]}\end{array}$} & \multicolumn{2}{|c|}{$\begin{array}{c}\mathrm{ZEN} \\
{[\mu \mathrm{gg} / \mathrm{kg}]}\end{array}$} \\
\hline & & Mean & SD & Mean & SD & Mean & SD & Mean & SD \\
\hline 1 & Cicibór & 2295 & 620 & 76.3 & 7.6 & 53.7 & 0.4 & 17.9 & 17.9 \\
\hline 2 & Czesławice & 4126 & 1319 & 181.4 & 37.4 & 63.7 & 0.0 & 93.1 & 35.2 \\
\hline 3 & Głębokie & 842 & 203 & 63.5 & 7.4 & 59.5 & 1.1 & 18.1 & 18.1 \\
\hline 4 & Głubczyce & 2919 & 969 & 127.2 & 35.5 & 60.7 & 5.6 & 26.8 & 26.8 \\
\hline 5 & Kawęczyn & 55 & 54 & 61.1 & 2.9 & 51.8 & 1.6 & 0 & 0 \\
\hline 6 & Krościna Mała & 1327 & 1276 & 61.0 & 7.1 & 52.2 & 0.5 & 0 & 0 \\
\hline 7 & Lućmierz & 315 & 36 & 110.7 & 54.3 & 61.5 & 8.0 & 0 & 0 \\
\hline 8 & Marianowo & 1743 & 948 & 53.3 & 1.4 & 52.1 & 0.1 & 0 & 0 \\
\hline 9 & Masłowice & 650 & 203 & 65.3 & 9.4 & 51.7 & 1.7 & 10.6 & 10.6 \\
\hline 10 & Naroczyce & 38 & 38 & 63.0 & 5.3 & 50.8 & 1.9 & 9.9 & 9.9 \\
\hline 11 & Nowa Wieś Ujska & 65 & 65 & 51.9 & 1.7 & 50.3 & 1.1 & 10,1 & 10.1 \\
\hline 12 & Radostowo & 3466 & 1428 & 58.6 & 1.9 & 53.0 & 0.2 & 0 & 0 \\
\hline 13 & Rarwino & 108 & 108 & 53.5 & 3.3 & 52.8 & 1.1 & 0 & 0 \\
\hline 14 & Ruska Wieś & 951 & 73 & 55.4 & 2.7 & 51.8 & 0.7 & 13.5 & 13.5 \\
\hline 15 & Rychliki & 3230 & 2138 & 87.9 & 9.2 & 54.3 & 0.6 & 42.0 & 21.5 \\
\hline 16 & Seroczyn & 731 & 731 & 78.1 & 15.0 & 54.6 & 3.4 & 27.6 & 27.6 \\
\hline 17 & Słupia & 1116 & 474 & 107.3 & 27.7 & 53.6 & 3.7 & 36.9 & 36.9 \\
\hline 18 & Świebodzin & 303 & 165 & 51.2 & 1.8 & 51.9 & 0.2 & 13.8 & 13.8 \\
\hline 19 & Tarnów & 1213 & 14 & 89.1 & 28.5 & 54.8 & 4.5 & 0 & 0 \\
\hline 20 & Tomaszów Boles. & 231 & 148 & 76.3 & 3.5 & 55.1 & 0.2 & 0 & 0 \\
\hline 21 & Węgrzce & 927 & 451 & 86.9 & 7.2 & 56.5 & 3.3 & 20.1 & 20.1 \\
\hline 22 & Wrócikowo & 1679 & 723 & 165.8 & 96.7 & 61.6 & 9.2 & 0 & 0 \\
\hline 23 & Wyczechy & 645 & 288 & 83.0 & 24.0 & 56.7 & 5.4 & 0 & 0 \\
\hline 24 & Zadąbrowie & 19269 & 6931 & 420.3 & 131.7 & 57.7 & 1.3 & 227.0 & 21.3 \\
\hline 25 & Zybiszów & 1017 & 97 & 76.9 & 12.4 & 56.6 & 0.6 & 29.3 & 29.3 \\
\hline \multicolumn{2}{|c|}{ Mean } & 1970 & - & 96.2 & - & 55.2 & - & 23.9 & - \\
\hline \multirow{2}{*}{\multicolumn{2}{|c|}{$\begin{array}{l}\text { Mean 'Bogatka' } \\
\text { Mean 'Muszelka' }\end{array}$}} & 1430 & - & 78.2 & - & 53.4 & - & 11.4 & - \\
\hline & & 3770 & - & 114.2 & - & 56.9 & - & 36.3 & - \\
\hline
\end{tabular}

\footnotetext{
a - sum of biomasses of detected Fusarium species
} 
Five Fusarium species were detected in grain. Biomass of $F$. equiseti, F. sporotrichioides and $F$. tricinctum was not detected in any sample. The highest content of biomass was of $F$. graminearum $(1252 \mathrm{pg} / \mu \mathrm{g})$, then $F$. avenaceum $(259 \mathrm{pg} / \mu \mathrm{g}), F$. langsethiae $(237 \mathrm{pg} / \mu \mathrm{g})$ and $F$. poae $(168 \mathrm{pg} / \mu \mathrm{g})$ (Figure 3$)$. The content of biomass of $F$. culmorum $(55 \mathrm{pg} / \mu \mathrm{g})$ was very low. The most frequently occurring species were $F$. poae (detected in $74 \%$ of samples) and $F$. graminearum (detected in $52 \%$ of samples) (Figure 3 ). F. poae was the only species found in $18 \%$ of samples. F. langsethiae was detected in six samples (five from three locations in northern Poland - Wyczechy, Radostowo, Rychliki). The concentration of $F$. langsethiae in these samples was relatively high $1972 \mathrm{pg} / \mu \mathrm{g}$ compared with an average for samples containing F. graminearum DNA - $2235 \mathrm{pg} / \mu \mathrm{g}$. Lack of differences was confirmed by Kruskall-Wallis test.

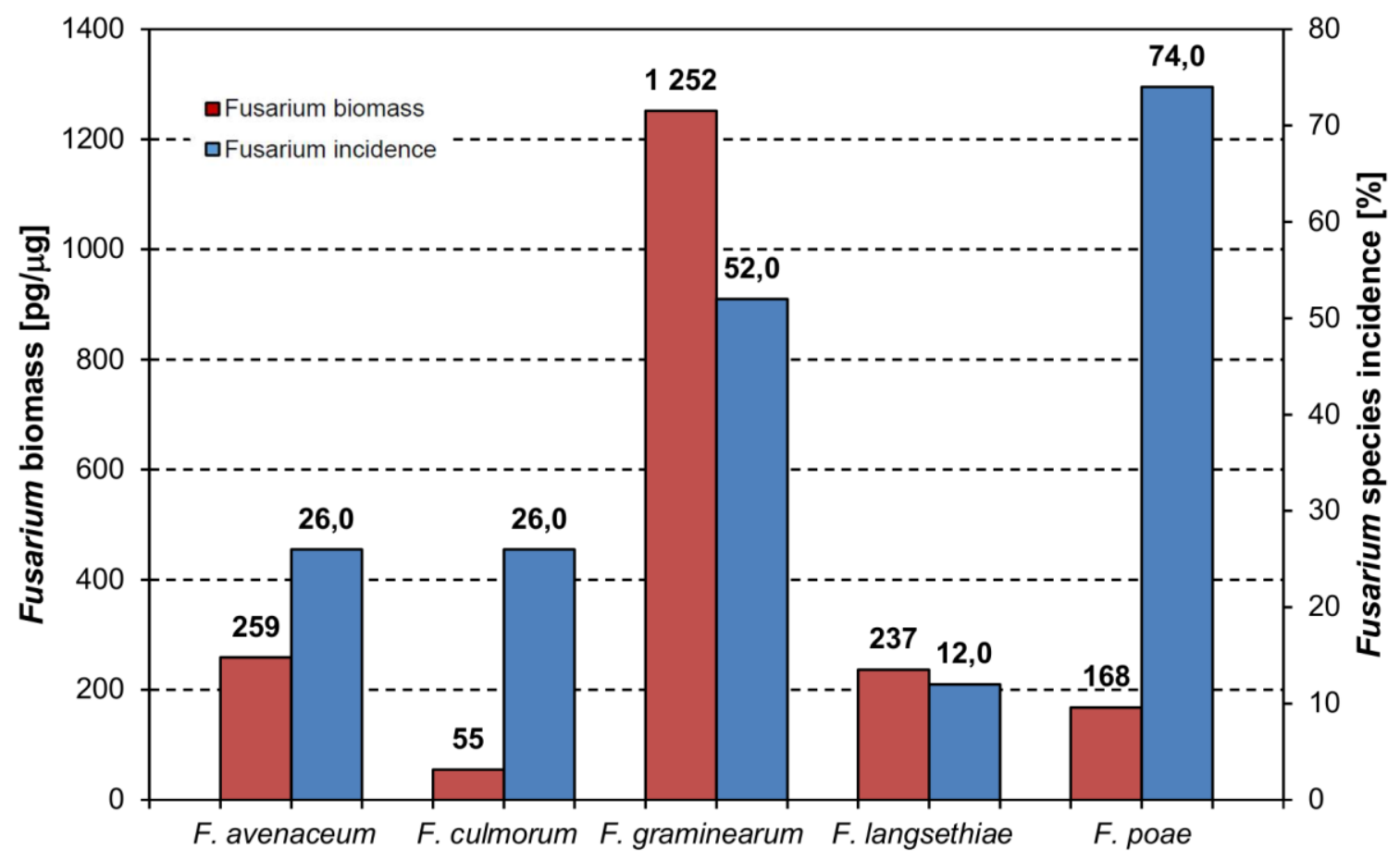

Fusarium species

Figure 3. Average concentration of biomass (pg of fungal DNA/ $\mu$ g of wheat DNA) and incidence (percentages) of five Fusarium species in 50 samples of winter wheat collected in Poland in 2010

$F$. poae was detected in all samples of medium resistant cultivar 'Bogatka' but only in $48 \%$ of samples of susceptible 'Muszelka'. Another species $F$. avenaceum was also found more frequently in grain of 'Bogatka' (32\%) than 'Muszelka' $(20 \%)$. Three other species ( $F$. culmorum, $F$. graminearum, $F$. langsethiae) were detected in grain of both cultivars with similar frequency.

Amounts of biomasses of Fusarium species weakly correlated with each other (Table 4). Only coefficient of correlation $F$. graminearum vs. F. culmorum was statistically significant. Positive relationship was found between $F$. avenaceum and $F$. culmorum or $F$. graminearum as biomass of the first species was mostly detected in the same locations as the other two species - 1, 4, 14, 19, 22 (only $F$. graminearum), and 24 . Biomass of $F$. langsethiae did not correlate with other species, as it was found only in six samples. Otherwise, $F$. poae biomass did not correlate with other species because as the species was present in the most of samples (74\%) and in the most samples (except two) amounts of $F$. poae biomass were similar. 
Table 4. Coefficients of correlation between concentrations of biomass (pg/ $\mu \mathrm{g}$ ) of five Fusarium species in grain of wheat collected in 2010 from 25 locations.

\begin{tabular}{lcccc}
\hline \multicolumn{1}{c}{ Species } & F. avenaceum & F. culmorum & F.graminearum & F. langsethiae \\
\hline F. culmorum & 0.306 & & & \\
F. graminearum & 0.162 & $\mathbf{0 . 4 6 1}$ & & \\
F. langsethiae & -0.315 & 0.066 & -0.148 & \\
F. poae & -0.083 & 0.049 & 0.005 & -0.058 \\
\hline
\end{tabular}

All variables were log transformed. Values in bold are different from 0 with a significance level $\mathrm{P} \leq 0.05$

Biplot produced by PCA analysis on biomass concentration of five Fusarium species showed uneven distribution of these species in different locations (Figure 4). F. culmorum was present mostly in the same locations as $F$. graminearum (except 12 ). $F$. avenaceum was present in the same six locations as $F$. culmorum and $F$. graminearum (except 22, where only the second species was detected). In three locations $(7,8,13)$ this species was accompanied only by $F$. poae. As it was mentioned earlier, $F$. langsethiae was found in four locations $(12,15,17,23)$. In Słupia (17), it was accompanied by $F$. culmorum and $F$. graminearum, in Radostowo (12) and Rychliki (15) by $F$. culmorum or $F$. graminearum, respectively.

\section{Biplot (axes D1 and D2: 56,75 \%) after Varimax rotation}

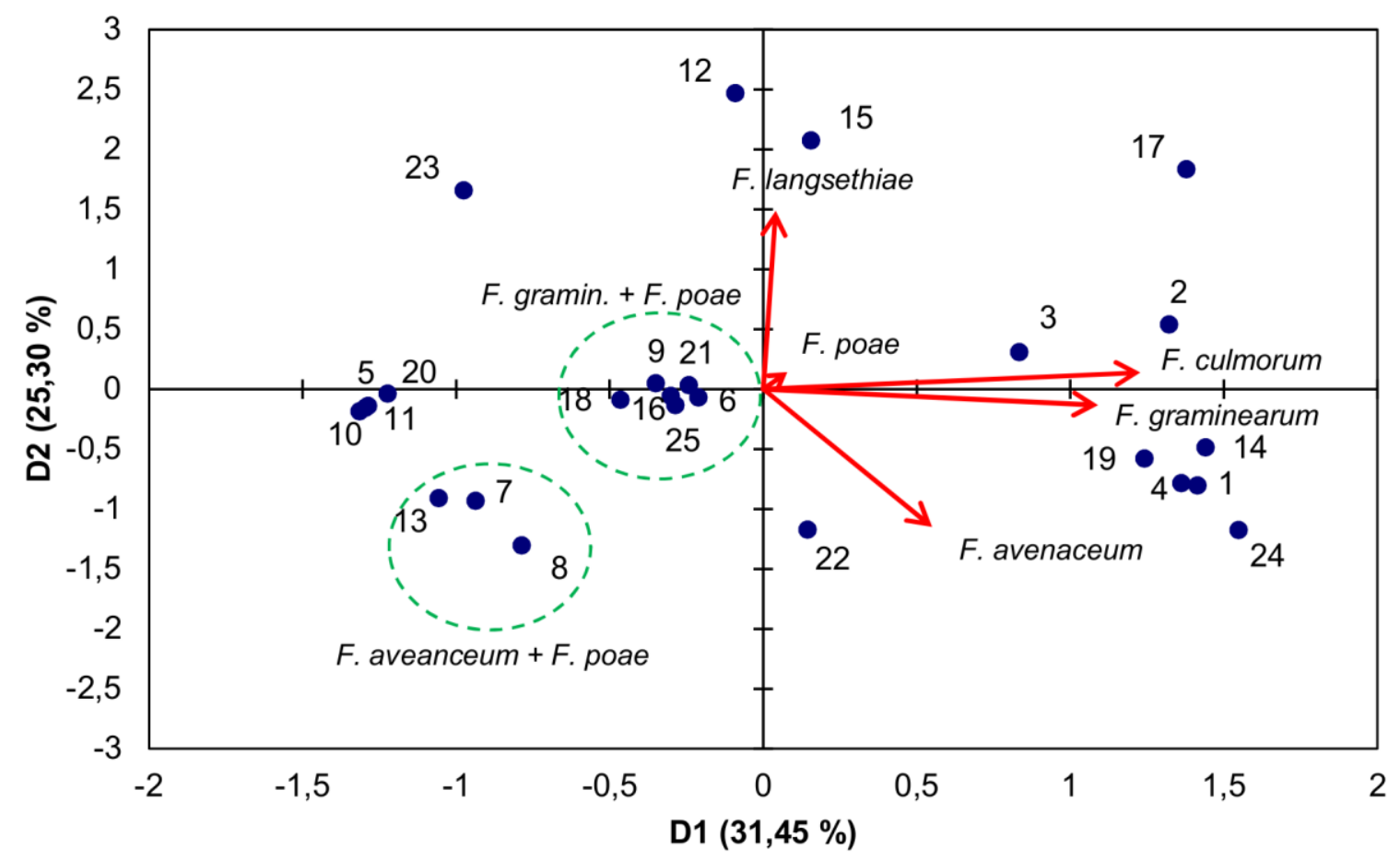

Figure 4. Principal Component Analysis based on biomass of Fusarium avenaceum, F. culmorum, F. graminearum, $F$. langsethiae and $F$. poae in 50 grain samples of winter wheat collected from 25 locations in Poland. Location numbers correspond to those in table 2. Variables were log transformed prior to the analysis

Average content of DON was low and amounted to $96.2 \mu \mathrm{g} / \mathrm{kg}$, at a range from.49.3 to 552.0 $\mu \mathrm{g} / \mathrm{kg}$ (Table 3). The content of NIV was very low $-55.2 \mu \mathrm{g} / \mathrm{kg}$, at a range $49.2-70.8 \mu \mathrm{g} / \mathrm{kg}$. The average content of DON for 'Bogatka' was $78.2 \mu \mathrm{g} / \mathrm{kg}$, and $114.2 \mu \mathrm{g} / \mathrm{kg}$ for 'Muszelka'. The highest concentration of DON was found in samples of both cultivars from Zadąbrowie and Czesławice, South-Eastern Poland (Figure 1). High concentration of this toxin was also found in samples of 'Muszelka' from Wrócikowo, Lućmierz and Głubczyce. 
ZEN was detected in $12 \%$ of samples of 'Bogatka' and in $60 \%$ of samples of 'Muszelka' cultivars. Average content was $23.9 \mu \mathrm{g} / \mathrm{kg}$ and was 3 times higher in grain of 'Muszelka' than in 'Bogatka'. High concentration of ZEN was present in samples of 'Muszelka' and 'Bogatka' from Zadąbrowie (248 and $206 \mu \mathrm{g} / \mathrm{kg}$, respectively) and in 'Muszelka' sample from Czesławice $(128 \mu \mathrm{g} / \mathrm{kg})$.

Table 5. Coefficients of correlation between concentration of biomass (pg/ $\mu \mathrm{g})$ of three Fusarium species and concentration $(\mu \mathrm{g} / \mathrm{kg})$ of mycotoxins DON, NIV and ZEN in grain of winter wheat cultivars 'Bogatka' and 'Muszelka' from 2010 harvest in 25 locations

\begin{tabular}{lcccccccc}
\hline \multicolumn{1}{c}{$\mathbf{n}=\mathbf{2 5}$} & $\boldsymbol{F u s a r i u m}$ & $\boldsymbol{F g}$ & $\boldsymbol{F c}$ & $\boldsymbol{F g}+\boldsymbol{F} \boldsymbol{c}$ & $\boldsymbol{F}$. poae & DON & NIV & ZEN \\
\hline DON & $\mathbf{0 . 6 2 2}$ & $\mathbf{0 . 5 3 4}$ & 0.320 & $\mathbf{0 . 5 0 9}$ & - & & & \\
NIV & $\mathbf{0 . 4 6 7}$ & 0.381 & 0.242 & 0.354 & 0.300 & $\mathbf{0 . 6 9 5}$ & & \\
ZEN & $\mathbf{0 . 4 0 0}$ & $\mathbf{0 . 6 7 2}$ & $\mathbf{0 . 4 0 6}$ & $\mathbf{0 . 6 5 8}$ & - & $\mathbf{0 . 4 3 8}$ & 0.186 & \\
Toxins & $\mathbf{0 . 6 4 9}$ & $\mathbf{0 . 6 0 9}$ & $\mathbf{0 . 3 6 5}$ & $\mathbf{0 . 5 8 7}$ & -0.035 & $\mathbf{0 . 9 7 4}$ & $\mathbf{0 . 6 4 3}$ & $\mathbf{0 . 6 1 2}$ \\
\hline
\end{tabular}

Values in bold are different from 0 with a significance level of $\mathrm{P} \leq 0.05$; all variables were log transformed. $F g-F$. graminearum, $F c-F$. culmorum, toxins - sum of DON, NIV and ZEN.

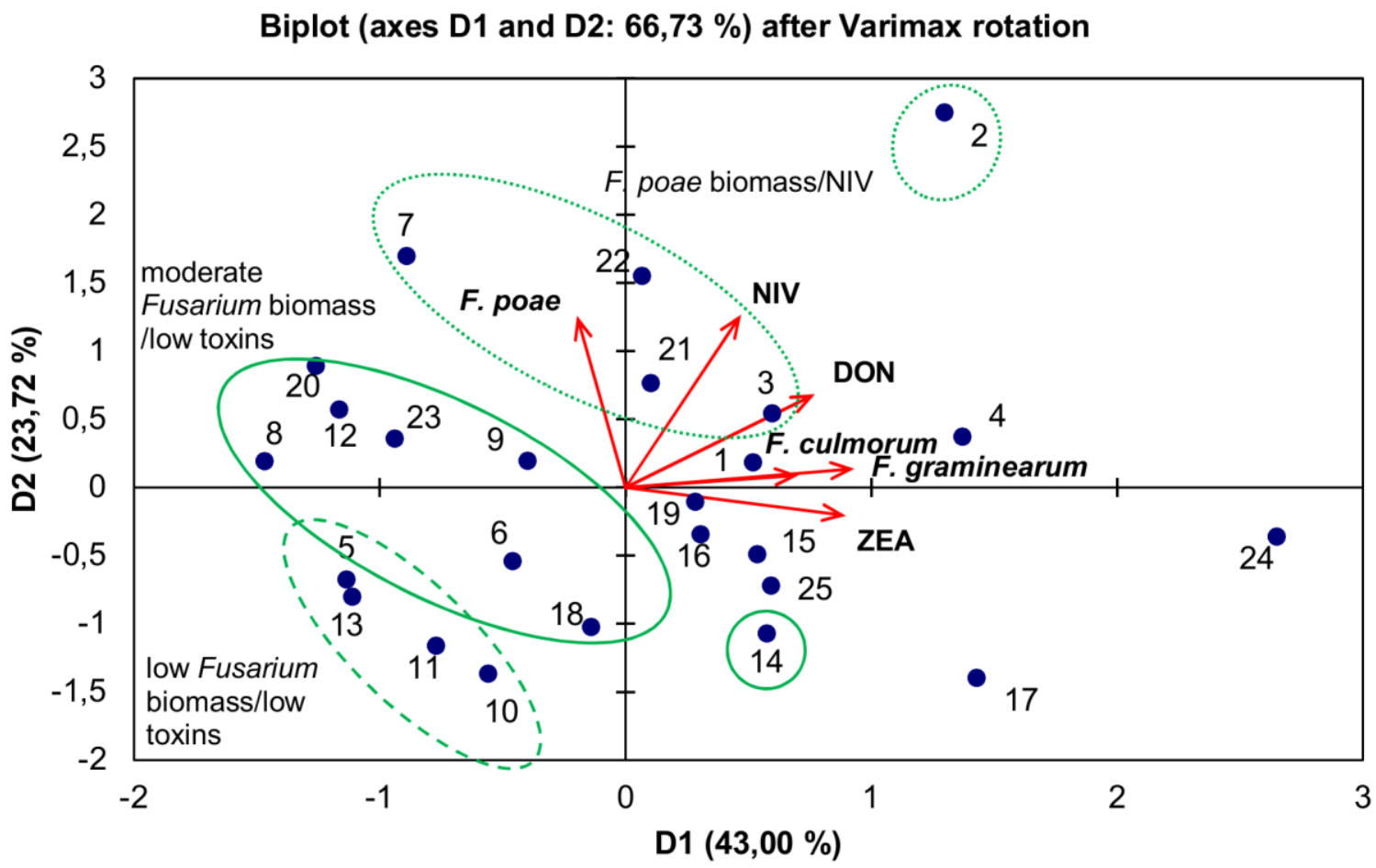

Figure 5. Principal Component Analysis based on biomass of Fusarium culmorum, F. graminearum and F. poae, and concentration of Fusarium toxins (DON, NIV, ZEN) in grain samples of winter wheat collected from 25 locations in Poland. Location numbers correspond to these in table 2. Variables were log transformed prior to the analysis.

Six samples of grain containing DNA of $F$. langsethiae were analysed for T-2/HT-2 toxins. In all samples, the total concentration of both mycotoxins was below detection limit of $35 \mu \mathrm{g} / \mathrm{kg}$. Amount of Fusarium biomass in grain correlated significantly with concentration of Fusarium toxins (DON, NIV, ZEN) (Table 5). F. graminearum correlated significantly with DON and ZEN concentrations, whereas $F$. culmorum with ZEN concentration only. Biomass of $F$. poae did not correlate with DON and ZEN - toxins not produced by this species. There was some positive relationship between $F$. poae and NIV concentration. Summarised amount of $F$. culmorum and $F$. graminearum biomasses did not improve the strength of correlation with 
toxins. Correlation of NIV vs. F. graminearum $+F$. poae (possible NIV producers) was statistically significant $(\mathrm{r}=0.511)$.

Biplot produced by PCA analysis distinguished some locations based on concentrations of biomass of three Fusarium species and Fusarium toxins (Figure 5). In Zadąbrowie (24) we found the highest amount of DON and ZEN as well as amount of $F$. graminearum biomass. Grain from Czesławice (2) were characterised by the highest amounts of $F$. poae biomass and NIV but also have high concentrations of the others toxins/biomasses. On the other hand, in Słupia (17) concentration of $F$. poae biomass and NIV was low, but analysis showed high concentration of $F$. culmorum accompanied by moderate concentration of $F$. graminearum and DON.

In the five locations $(5,10,11,13)$ the concentration of biomass of three Fusarium species as well as the concentration of toxins were low. In another eight locations (Figure 5, solid line), concentration of toxins was low but amount of Fusarium biomass varied from low (23) to high (6). In Ruska Wieś (14) we found the highest concentration of F. culmorum biomass (511.8 $\mathrm{pg} / \mu \mathrm{g})$. Five locations $(2,3,7,21,22)$ could be characterised by above average concentration of NIV and moderate to high concentration of $F$. poae biomass. This species was present at considerable amounts also in other locations $(1,8,9,12,20)$ but NIV concentration was low. In samples of grain of spring and winter wheat collected from Radzików and neighbouring Młochów we found more Fusarium biomass than in the majority of samples of 'Bogatka' and 'Muszelka' (Table 6). The highest amount of biomass was present in samples of winter wheat

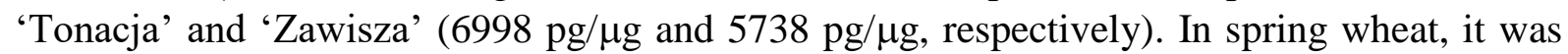
lower, except for the sample of 'Raweta' from Radzików (Raweta R1) (5513 pg/ $\mu \mathrm{g}$ ).

Four Fusarium species were detected in grain. F. langsethiae and $F$. sporotrichioides were not present. F. avenaceum dominated in three samples (on average $1797 \mathrm{pg} / \mu \mathrm{g}$ of biomass) and $F$. graminearum also in three $(1432 \mathrm{pg} / \mu \mathrm{g})$. In one sample (Tonacja $\mathrm{R}$ ) amounts of biomass of these species were similar. $F$. poae was present in all samples of winter wheat $(270 \mathrm{pg} / \mu \mathrm{g})$. In grain of spring wheat 'Raweta' from Młochów only this species was present. The concentration of $F$. culmorum biomass was generally the lowest of all species $(67 \mathrm{pg} / \mu \mathrm{g})$.

Table 6. Concentration of biomass of four Fusarium species, and DON and NIV mycotoxins levels in grain of spring and winter wheat from 2010 harvest in Radzików (R) and Mlochow (M)

\begin{tabular}{cccccccc}
\multirow{2}{*}{ No. } & \multirow{2}{*}{$\begin{array}{c}\text { Cultivar/ } \\
\text { location }\end{array}$} & \multicolumn{4}{c}{$\begin{array}{c}\text { Fusarium biomass } \\
{[\mathbf{p g} / \boldsymbol{\mu g}]}\end{array}$} & \multicolumn{2}{c}{$\begin{array}{c}\text { Fusarium toxins } \\
{[\boldsymbol{\mu g} / \mathbf{k g}]}\end{array}$} \\
\cline { 3 - 8 } & & avenaceum & culmorum & graminearum & poae & DON & NIV \\
\hline 1 & Griwa (R) & 587 & 70 & 1146 & 262 & 60,8 & 50,4 \\
2 & Parabola (R) & 874 & 65 & 257 & 59 & 58,1 & 50,9 \\
3 & Raweta (R) & 0 & 57 & 379 & 58 & 61,6 & 50,0 \\
4 & Raweta (R1) & 3522 & 159 & 1671 & 161 & 92,1 & 51,1 \\
5 & Raweta (M) & 0 & 0 & 0 & 244 & 53,0 & 49,7 \\
6 & Tonacja (R) & 3223 & 0 & 2566 & 434 & 64,6 & 52,3 \\
7 & Tonacja (M) & 6169 & 0 & 0 & 829 & 54,5 & 50,9 \\
8 & Zawisza (R) & 0 & 181 & 5441 & 116 & 135,3 & 52,6 \\
\hline & Mean & $\mathbf{1 7 9 7}$ & $\mathbf{6 7}$ & $\mathbf{1 4 3 2}$ & $\mathbf{2 7 0}$ & $\mathbf{7 2 , 5}$ & $\mathbf{5 1 , 0}$ \\
\hline
\end{tabular}

The concentration of trichothecene toxins was low (Table 6). ZEN amount was below limit of detection. The highest concentration of DON was found in samples with high concentration of $F$. graminearum and $F$. culmorum - Zawisza $\mathrm{R}$ and Raweta $\mathrm{R} 1$. The same was true for NIV concentration in grain. No relation was found between $F$. poae and NIV; however, total concentration of $F$. graminearum and $F$. poae correlated the best with NIV amount. 


\section{Discussion}

Presence and concentration of Fusarium toxins in naturally infected wheat is generally in accordance with data on occurrence of Fusarium species on wheat in Poland. According to the published data, dominant species on wheat spikes and kernels were $F$. culmorum, $F$. graminearum, $F$ avenaceum and $F$. poae (Bottalico and Perrone, 2002; Chełkowski et al., 2012; Perkowski et al., 1990). Proportions of these four species changed depending on year and study. F. graminearum was the dominating species in wheat grain in both 2009 and 2010. In 2009 it was present in all samples, and in 2010 in 52\%. Both years the average amount of $F$. graminearum biomass in grain was the highest of all investigated Fusarium species. $F$. culmorum was found in 2009 in $90 \%$ of samples; however, the biomass concentration of this species was approximately five times less than $F$. graminearum. F. culmorum prevailed only in one sample of grain. In 2010, F. culmorum was present in $31 \%$ of samples; however, its amount was the lowest among five identified species. Weather in 2009 was more favourable for FHB development than in 2010, which is also reflected in the difference in amount of Fusarium DNA and mycotoxins. In some regions (e.g. Radzików) in 2010, the drought conditions occurred in June and July with high temperatures and infrequent, heavy rainfalls. Despite differences in weather and limited number of samples in 2009, F. graminearum was occurring more frequently than $F$. culmorum. Amount of biomass of the first species was also higher in both years. While $F$. culmorum biomass was very low in 2010, we can conclude that dry weather is affecting to large extent presence of this species. In the Netherlands in 2009 incidence and amount of $F$. culmorum DNA was similarly low as in our study (van der Fels-Klerx et al., 2012). Authors found this species only in $2 \%$ of samples and DNA concentration was 80 -times lower than for $F$. graminearum.

In the paper of Wiśniewska et al. (2014) authors found that $F$. culmorum was the most common species on heavy infected heads of wheat in 2009. They analysed samples from six locations, and only in two in southern Poland F. graminearum prevailed over F. culmorum. These difference with our results could be effect of low number of locations sampled in (Wiśniewska et al., 2014) paper as well as in present study (ten locations). The number of examined heads could be the next reason of results difference. In Radzików authors, sampled 16 symptomatic heads whereas in our research we analysed grain from five fields or plots harvested with combine and next sampled for analysis. Wiśniewska et al. (2014) used method of isolation of Fusarium species from infected kernels and next identification of pure cultures.

The issue of sampling was studied and discussed by van der Fels-Klerx et al. (2012). They found significant difference between pre-harvest and at harvest samples. Some species $(F$. langsethiae, F. avenaceum) were not found (using real-time PCR) in pre-harvest samples, but detected in harvested grain. In inoculation experiment with different species Xu et al. (2007) found that correlation between FHB symptoms on heads and Fusarium biomass in grain was weak for $F$. culmorum and $F$. poae comparing with $F$. graminearum. Authors suggest that $F$. culmorum and $F$. poae colonised mainly floral tissues and to the lesser extent kernels. On the contrary, $F$. graminearum might colonise both tissue types to a similar degree.

Tomczak et al. (2002) analysed Fusarium species causing Fusarium head blight epidemics in 1998 and 1999 in two regions of Poland. In 1998 in northern and central regions $F$. avenaceum dominated, being followed by Fusarium graminearum and $F$. culmorum with similar frequency. In 1999, ranking of species was the same; however, frequency of $F$. graminearum was 3-5 times higher than $F$. culmorum. Authors reminds that no $F$. graminearum was detected in the previous decade (1980's) in wheat grown in northern Poland.

Stępień and Chełkowski (2010) summarized frequencies of Fusarium species infecting wheat heads in Poland from 1985 to 2009. In 1985 F. avenaceum and Microdochium nivale dominated, F. culmorum being the third species. In 2009, F. graminearum dominated and $F$. 
culmorum was the second species with about half frequency of first species. Increase of $F$. graminearum was obvious; however, differences between particular years were substantial.

Fusarium graminearum is the anamorph of Gibberella zeae, which produces sexual spores (ascospores) in perithecia. For F. culmorum species perfect stage is not known and fungus produces only asexual spores - macroconidia (Scherm et al., 2013). Thus $F$. graminearum can disperse and infect host plants with ascospores and macroconidia, whereas $F$. culmorum only with macroconidia. Nature of Gibberella zeae is the homothallic which allows the production of large masses of ascospores and effectively compete against $F$. culmorum (Waalwijk et al., 2003). In a recent study in Germany, the important contribution of ascospores to inoculum pressure was emphasized (Obst et al., 2002). Ascospores required a relative humidity below $53 \%$, whereas macroconidia required relative humidity of above $80 \%$ for germination, as was observed by Beyer et al. (2005). It can be another factor favouring $F$. graminearum over $F$. culmorum under dry conditions.

Deoxynivalenol (DON) was the most frequently detected toxin in the samples and its accumulation was the most closely associated with the presence of Fusarium graminearum. Coefficient was very high in 2009, because of high DON accumulation and high $F$. graminearum biomass amount in grain. In this year DON concentration correlated strongly also with $F$. culmorum biomass despite its low concentration in the most of samples. In 2010, coefficients were lower and significant only for $F$. graminearum.

Nivalenol (NIV) accumulation was much lower but significantly associated with the presence of $F$. graminearum and $F$. poae in 2009. In 2010, coefficients were insignificant but positive for all three possible NIV producers: $F$. culmorum, $F$. graminearum and $F$. poae. Xu et al. (2003) studied wheat grain samples harvested in 2001 from UK, Ireland, Italy and Hungary. They did not found quantitative relationships between amount of Fusarium DNA and the concentration of the mycotoxins in the grain. However, for total $F$. graminearum and $F$. culmorum DNA and DON concentration linear model was nearly significant. In the next survey (Xu et al., 2008b) they studied Fusarium species frequency and mycotoxin content in wheat samples from the same countries over two years (2003-2004). They found DON being the most frequently detected toxin. DON amount correlated strongly with $F$. graminearum DNA. NIV was related significantly only to the amount of $F$. culmorum DNA. As regards ZEN, authors found strong association with both $F$. culmorum and $F$. graminearum.

In 2005 in Poland the highest amount of zearalenone was found in wheat grain infected by $F$. graminearum (Gromadzka et al., 2008) In grains were $F$. culmorum was the main pathogen, zearalenone content was 10-times lower.

Fusarium poae was the most frequently species detected in grain (100\% of samples in 2009 and $74 \%$ of samples in 2010). In 2010 in 9 samples out of 50 it was the only Fusarium species present. However, amount of $F$. poae biomass was about 10-times lower then $F$. graminearum biomass in dry 2010 year and up to 200 times lower in year 2009 of weather favourable for Fusarium head blight. According to other reports $F$. poae was frequently isolated from wheat spikes and kernels in Poland (Goliński et al., 1996). This is weak pathogen of cereal spikes, however is widespread on wheat in Europe (Isebaert et al., 2009; Vogelgsang et al., 2008; Xu et al., 2003). Audenaert et al. (2009) observed dominance of this species in Flanders in years 2007 and it was isolated with lower frequency in 2008. In year 2007, the infection pressure was very high as compared with 2008. Author explained this fact as a result of $F$. poae nature as a secondary pathogen. Additionally, high frequency of occurrence of $F$. poae was explained by its sporulation strategy. This species produces very large amounts of small microconidia in a dry powdery form that can easily invade cereal heads. It could be true for dry conditions and wind dispersal, because for splash dispersal Hörberg (2002) did not find any difference in patterns between $F$. poae microconidia and much larger macroconidia of $F$. culmorum. 
$\mathrm{Xu}$ et al. (2008a) associated $F$. poae with relatively dry and warm conditions, whereas $F$. graminearum with warm/humid conditions. $F$. avenaceum and $F$. culmorum were both associated with niches of cooler/wet/humid conditions. Parikka et al. (2012) who expected increase of importance of $F$. poae (accompanied by $F$. langsethiae) in more dry conditions of Scandinavia stated the similar. The weather conditions in the most regions of Poland in 2010 were dry and warm during and after flowering. Results showed that this favoured $F$. poae spread on wheat. As only in the south/south-eastern Poland weather was warm and humid, $F$. graminearum dominated in grain from this region.

Low $F$. poae biomass in grain observed in our study could be explained by lower aggressiveness of this species as compared to F. graminearum (Stenglein, 2009; Vogelgsang et al., 2008). It was also found that $F$. poae that predominated in wheat glumes was not detected in grain, which was infected by $F$. culmorum, $F$. avenaceum and M. nivale (Doohan et al., 1998). Authors did not detect $F$. graminearum in wheat samples (collected in England, UK in 1994) which is good example of later Fusarium species shift in Europe. Polley and Turner (Polley and Turner, 1995) found that $F$. poae was associated with distinct glume spot lesions and was the most frequently isolated from glumes. Doohan et al. (1998) supposed that the infection process and colonization by $F$. poae differs from that of other Fusarium species causing FHB.

Fusarium poae is known as NIV producer (Schollenberger et al., 2006; Thrane et al., 2004). Consequently, we detected NIV in the majority of samples but at very low quantities. In Poland NIV was found primarily in oats infected by F. poae (Perkowski et al., 1997). Edwards et al. (2012) found that correlation of nivalenol concentration in oat grain and $F$. poae DNA was highly significant but only accounted for $9 \%$ of the variance. It showed that other species such as $F$. graminearum and $F$. culmorum were involved in NIV production. NIV chemotypes of these species are not frequent in Poland. Stępien et al. (2008) found that only $12 \%$ of $F$. graminearum isolates in Poland displayed the NIV chemotype.

Besides NIV $F$. poae isolates were found to produce wide range of toxins including trichothecens of type A and B, beauvericin, enniatins, moniliformin, and others (Bottalico and Perrone, 2002; Somma et al., 2010; Stenglein, 2009; Thrane et al., 2004; Uhlig et al., 2006). The surveys of wheat harvested in Poland in 2006 and 2007 showed that increased importance of $F$. poae in the FHB complex in Poland (Kulik and Jestoi, 2009).

In 1994 Norwegian researchers found "powdery $F$. poae" strains which were the most abundant potential producer of HT-2 and T-2 toxins in cereals (Kosiak et al., 2003). In 1999 these F. poae strains were proved to produce T-2 toxin (Torp and Langseth, 1999). Strains originated mainly from Norwegian oats but where found also on wheat in Austria and the Netherlands. Further Torp and Nierenberg (2004) described these strains as a new species F. langsethiae. The species was being found primarily in northern Europe on oats and barley (Edwards et al., 2012; Yli-Mattila et al., 2008). Occurrence of F. langsethiae on wheat in Poland was confirmed in 2008 (Lukanowski et al., 2008). This species was found mainly in northern Poland (including Radostowo mentioned in present study), however it was present in some samples of wheat grain from Central Poland (Lukanowski and Sadowski, 2008).In 2009 F. langsethiae was found on wheat grain in the Netherlands but at low level (8\% of samples) (van der Fels-Klerx et al., 2012). Presence of $F$. langsethiae was detected by Czaban et al. (2015) in years $2008-2010$ in south-eastern Poland. Percentages of winter wheat kernels colonised by this species was low. It ranged from 0 to $2.9 \%$ in susceptible cultivar 'Kris' in 2010 . In our research, we did not detected $F$. langsethiae in 2009, however limited number of samples was analysed. In 2010, DNA of this species was found mainly in samples from northern Poland and in only one from southern region at low concentration.

F. langsethiae and F. poae are favoured by dry conditions (Parikka et al., 2012), however it seems that the first species prefer lower temperatures than the former. Kokkonen et al. (2012) 
found that $F$. langsethiae produced the highest amount of the type-A trichothecenes at $15^{\circ} \mathrm{C}$, whereas $F$. poae could produce beauvericin at both cool and warm conditions.

\section{References}

Audenaert, K., van Broeck, R., van Bekaert, B., de Witte, F., Heremans, B., Messens, K., Höfte, M., Haesaert, G., Broeck, R., Bekaert, B., Witte, F., Heremans, B., Messens, K., Höfte, M. and Haesaert, G., 2009. Fusarium head blight (FHB) in Flanders: population diversity, inter-species associations and DON contamination in commercial winter wheat varieties. European Journal of Plant Pathology 125: 445-458.

Beyer, M., Verreet, J.-A. and Ragab, W.S.M., 2005. Effect of relative humidity on germination of ascospores and macroconidia of Gibberella zeae and deoxynivalenol production. International Journal of Food Microbiology 98: 233-40.

Birzele, B., Meier, A., Hindorf, H., Krämer, J. and Dehne, H.W., 2002. Epidemiology of Fusarium infection and deoxynivalenol content in winter wheat in the Rhineland, Germany. European Journal of Plant Pathology 108: 667-673.

Bottalico, A., 1998. Fusarium diseases of cereals: Species complex and related mycotoxin profiles, in Europe. Journal of Plant Pathology 80: 85-103.

Bottalico, A. and Perrone, G., 2002. Toxigenic Fusarium species and mycotoxins associated with head blight in small-grain cereals in Europe. European Journal of Plant Pathology 108: 611-624.

Chandelier, A., Nimal, C., André, F., Planchon, V. and Oger, R., 2011. Fusarium species and DON contamination associated with head blight in winter wheat over a 7-year period (2003-2009) in Belgium. European Journal of Plant Pathology 130: 403-414.

Chełkowski, J., Gromadzka, K., Stępień, Ł., Lenc, L., Kostecki, M. and Berthiller, F., 2012. Fusarium species, zearalenone and deoxynivalenol content in preharvest scabby wheat heads from Poland. World Mycotoxin Journal 5: 133-141.

Czaban, J., Wróblewska, B., Sułek, A., Mikos, M., Boguszewska, E., Podolska, G. and Nieróbca, A., 2015. Colonisation of winter wheat grain by Fusarium spp. and mycotoxin content as dependent on a wheat variety, crop rotation, a crop management system and weather conditions. Food Additives and Contaminants. Part A, Chemistry, Aanalysis, Control, Exposure and Risk Assessment 32: 799-807.

Doohan, F.M., Parry, D.W., Jenkinson, P. and Nicholson, P., 1998. The use of species-specific PCR-based assays to analyse Fusarium ear blight of wheat. Plant Pathology 47: 197-205.

Edwards, S.G., Imathiu, S.M., Ray, R. V., Back, M. and Hare, M.C., 2012. Molecular studies to identify the Fusarium species responsible for HT-2 and T-2 mycotoxins in UK oats. International Journal of Food Microbiology Elsevier B.V., 156: 168-175.

Giraud, F., Pasquali, M., El Jarroudi, M., Vrancken, C., Brochot, C., Cocco, E., Hoffmann, L., Delfosse, P. and Bohn, T., 2010. Fusarium head blight and associated mycotoxin occurrence on winter wheat in Luxembourg in 2007/2008. Food additives \& contaminants. Part A, Chemistry, analysis, control, exposure \& risk assessment 27: 825-35.

Goliński, P., Perkowski, J., Kostecki, M., Grabarkiewicz-Szczęsna, J. and Chełkowski, J., 1996. Fusarium species and Fusarium toxins in wheat in Poland - a comparison with neighbour countries. Sydowia 48: 12-22.

Gromadzka, K., Chełkowski, J., Stępień, Ł. and Goliński, P., 2008. Occurrence of zearalenone in wheat and maize grain in Poland. Cereal Research Communications 36: 361-363.

Hörberg, H.M., 2002. Patterns of splash dispersed conidia of Fusarium poae and Fusarium culmorum. European Journal of Plant Pathology 108: 73-80.

Horevaj, P., Milus, E.A. and Bluhm, B.H., 2011. A real-time qPCR assay to quantify Fusarium graminearum biomass in wheat kernels. Journal of Applied Microbiology 111: 396-406. 
Isebaert, S., De Saeger, S., Devreese, R., Verhoeven, R., Maene, P., Heremans, B. and Haesaert, G., 2009. Mycotoxin-producing Fusarium species occurring in winter wheat in Belgium (Flanders) during 2002-2005. Journal of Phytopathology 157: 108-116.

Jestoi, M.N., Paavanen-Huhtala, S., Parikka, P. and Yli-Mattila, T., 2008. In vitro and in vivo mycotoxin production of Fusarium species isolated from Finnish grains. Archives of Phytopathology and Plant Protection 41: 545-558.

Kokkonen, M., Jestoi, M. and Laitila, A., 2012. Mycotoxin production of Fusarium langsethiae and Fusarium sporotrichioides on cereal-based substrates. Mycotoxin Research 28: 2535.

Kosiak, B., Torp, M., Skjerve, E. and Thrane, U., 2003. The prevalence and distribution of Fusarium species in Norwegian cereals: a survey. Acta Agriculturae Scandinavica, Section B - Soil and Plant Science 53: 168-176.

Kulik, T. and Jestoi, M., 2009. Quantification of Fusarium poae DNA and associated mycotoxins in asymptomatically contaminated wheat. International Journal of Food Microbiology Elsevier B.V., 130: 233-237.

Laszlo, E., Varga, B. and Veisz, O., 2011. Composition of Fusarium species causing natural spike infection in wheat. Acta Agronomica Hungarica 59: 255-260.

Lukanowski, A., Lenc, L. and Sadowski, C., 2008. First Report on the occurrence of Fusarium langsethiae isolated from wheat Kernels in Poland. Plant Disease 92: 488-488.

Lukanowski, A. and Sadowski, C., 2008. Fusarium langsethiae on kernels of winter wheat in Poland - Occurrence and mycotoxigenic abilities. Cereal Research Communications 36: 453-457.

Miller, J.D., 2008. Mycotoxins in small grains and maize: old problems, new challenges. Food additives \& contaminants. Part A, Chemistry, analysis, control, exposure \& risk assessment 25: 219-30.

Nicolaisen, M., Suproniene, S., Nielsen, L.K., Lazzaro, I., Spliid, N.H. and Justesen, A.F., 2009. Real-time PCR for quantification of eleven individual Fusarium species in cereals. Journal of Microbiological Methods 76: 234-240.

Nielsen, L.K., Jensen, J.D., Nielsen, G.C., Jensen, J.E., Spliid, N.H., Thomsen, I.K., Justesen, A.F., Collinge, D.B. and Jørgensen, L.N., 2011. Fusarium head blight of cereals in Denmark: species complex and related mycotoxins. Phytopathology 101: 960-969.

Nielsen, L.K., Justesen, A.F., Jensen, J.D. and Jørgensen, L.N., 2013. Microdochium nivale and Microdochium majus in seed samples of Danish small grain cereals. Crop Protection Elsevier Ltd, 43: 192-200.

Niessen, L., 2007. PCR-based diagnosis and quantification of mycotoxin producing fungi. International Journal of Food Microbiology 119: 38-46.

Obst, A., Gunther, B., Beck, R., Lepschy-von Gleissenthall, J. and Tischner, H., 2002. Weather conditions conducive to Gibberella zeae and Fusarium graminearum head blight of wheat. Journal of Applied Genetics 43A: 185-192.

Obst, A., Lepschy-von Gleissenthall, J. and Beck, R., 1997. On the etiology of Fusarium head blight of wheat in south Germany - preceding crops, weather conditions for inoculum production and head infection, proneness of the crop to infection and mycotoxin production. Cereal Research Communications Akadémiai Kiadó, 25: 699-703.

Parikka, P., Hakala, K. and Tiilikkala, K., 2012. Expected shifts in Fusarium species' composition on cereal grain in Northern Europe due to climatic change. Food Additives and Contaminants. Part A, Chemistry, Analysis, Control, Exposure and Risk Assessment 29: $1543-55$.

Parry, D.W., Jenkinson, P. and McLeod, L., 1995. Fusarium ear blight (scab) in small grain cereals - a review. Plant Pathology Blackwell Publishing Ltd, 44: 207-238.

Perkowski, J., Plattner, R.D., Golinski, P., Vesonder, R.F. and Chelkowski, J., 1990. Natural 
occurrence of deoxynivalenol, 3-acetyl-deoxynivalenol, 15-acetyl-deoxynivalenol, nivalenol, 4,7-dideoxynivalenol, and zearalenone in Polish wheat. Mycotoxin Research 6: $7-12$.

Perkowski, J., Stachowiak, J., Kiecana, I., Golinski, P. and Chelkowski, J., 1997. Natural occurrence of Fusarium mycotoxins in Polish cereals. Cereal Research Communications 25: 379-380.

Polley, R.W. and Turner, J.A., 1995. Surveys of stem base diseases and fusarium ear diseases in winter wheat in England, Wales and Scotland, 1989-1990. Annals of Applied Biology 126: 45-59.

Scherm, B., Balmas, V., Spanu, F., Pani, G., Delogu, G., Pasquali, M. and Migheli, Q., 2013. Fusarium culmorum: causal agent of foot and root rot and head blight on wheat. Molecular Plant Pathology 14: 323-41.

Schollenberger, M., Müller, H.M., Rüfle, M., Suchy, S., Plank, S. and Drochner, W., 2006. Natural occurrence of 16 Fusarium toxins in grains and feedstuffs of plant origin from Germany. Mycopathologia 161: 43-52.

Somma, S., Alvarez, C., Ricci, V., Ferracane, L., Ritieni, A., Logrieco, A. and Moretti, A., 2010. Trichothecene and beauvericin mycotoxin production and genetic variability in Fusarium poae isolated from wheat kernels from northern Italy. Food Additives and Contaminants - Part A Chemistry, Analysis, Control, Exposure and Risk Assessment 27: 729-737.

Stenglein, S.A., 2009. Fusarium poae: A pathogen that needs more attention. Journal of Plant Pathology 91: 25-36.

Stępień, Ł. and Chełkowski, J., 2010. Fusarium head blight of wheat: pathogenic species and their mycotoxins. World Mycotoxin Journal 3: 107-119.

Stępień, Ł., Popiel, D., Koczyk, G. and Chełlkowski, J., 2008. Wheat-infecting Fusarium species in Poland-their chemotypes and frequencies revealed by PCR assay. Journal of applied genetics 49: 433-441.

Talas, F., Parzies, H.K. and Miedaner, T., 2011. Diversity in genetic structure and chemotype composition of Fusarium graminearum sensu stricto populations causing wheat head blight in individual fields in Germany. European Journal of Plant Pathology 131: 39-48.

Thrane, U., Adler, A., Clasen, P.-E., Galvano, F., Langseth, W., Lew, H., Logrieco, A., Nielsen, K.F. and Ritieni, A., 2004. Diversity in metabolite production by Fusarium langsethiae, Fusarium poae, and Fusarium sporotrichioides. International Journal of Food Microbiology 95: 257-66.

Tomczak, M., Wiśniewska, H., Stępień, Ł., Kostecki, M., Chełkowski, J. and Goliński, P., 2002. Deoxynivalenol, nivalenol and moniliformin in wheat samples with head blight (scab) symptoms in Poland (1998-2000). European Journal of Plant Pathology 108: 625630.

Torp, M. and Langseth, W., 1999. Production of T-2 toxin by a Fusarium resembling Fusarium poae. Mycopathologia 147: 89-96.

Torp, M. and Nirenberg, H.I., 2004. Fusarium langsethiae sp. nov. on cereals in Europe. International Journal of Food Microbiology 95: 247-256.

Uhlig, S., Jestoi, M. and Parikka, P., 2007. Fusarium avenaceum - the North European situation. International Journal of Food Microbiology 119: 17-24.

Uhlig, S., Torp, M. and Heier, B.T., 2006. Beauvericin and enniatins A, A1, B and B1 in Norwegian grain: A survey. Food Chemistry 94: 193-201.

van der Fels-Klerx, H.J., de Rijk, T.C., Booij, C.J.H., Goedhart, P.W., Boers, E.A.M., Zhao, C., Waalwijk, C., Mol, H.G.J. and van der Lee, T.A.J., 2012. Occurrence of Fusarium head blight species and Fusarium mycotoxins in winter wheat in the Netherlands in 2009. Food Additives and Contaminants - Part A Chemistry, Analysis, Control, Exposure and Risk 
Assessment 29: 1716-1726.

Vogelgsang, S., Sulyok, M., Hecker, A., Jenny, E., Krska, R., Schuhmacher, R. and Forrer, H.R., 2008. Toxigenicity and pathogenicity of Fusarium poae and Fusarium avenaceum on wheat. European Journal of Plant Pathology 122: 265-276.

Waalwijk, C., Kastelein, P., De Vries, I., Kerényi, Z., Van Der Lee, T., Hesselink, T., Köhl, J. and Kema, G., 2003. Major changes in Fusarium spp. in wheat in the Netherlands. European Journal of Plant Pathology 109: 743-754.

Waalwijk, C., Van Der Heide, R., De Vries, I., Van Der Lee, T., Schoen, C., Costrel-de Corainville, G., Häuser-Hahn, I., Kastelein, P., Köhl, J., Lonnet, P., Demarquet, T. and Kema, G.H.J., 2004. Quantitative detection of Fusarium species in wheat using TaqMan. European Journal of Plant Pathology 110: 481-494.

Wiśniewska, H., Stępień, Ł., Waśkiewicz, A., Beszterda, M., Góral, T. and Belter, J., 2014. Toxigenic Fusarium species infecting wheat heads in Poland. Open Life Sciences 9: 163172.

Xu, X.-M., Nicholson, P., Thomsett, M.A., Simpson, D., Cooke, B.M., Doohan, F.M., Brennan, J., Monaghan, S., Moretti, A., Mule, G., Hornok, L., Beki, E., Tatnell, J., Ritieni, A. and Edwards, S.G., 2008a. Relationship between the fungal complex causing Fusarium head blight of wheat and environmental conditions. Phytopathology 98: 69-78.

Xu, X., Parry, D.W., Nicholson, P., Thomsett, M.A., Simpson, D., Edwards, S.G., Cooke, B.M., Doohan, F.M., Van Maanen, A., Moretti, A., Tocco, G., Mule, G., Hornok, L., Giczey, G., Tatnell, J. and Ritieni, A., 2003. Is the amount of mycotoxins in cereal grains related to the quantity of Fusarium DNA? Aspects of Applied Biology 68: 101-108.

$\mathrm{Xu}, \mathrm{X} . \mathrm{M}$., Monger, W., Ritieni, A. and Nicholson, P., 2007. Effect of temperature and duration of wetness during initial infection periods on disease development, fungal biomass and mycotoxin concentrations on wheat inoculated with single, or combinations of Fusarium species. Plant Pathology 56: 943-956.

Xu, X.M., Parry, D.W., Nicholson, P., Thomsett, M. a., Simpson, D., Edwards, S.G., Cooke, B.M., Doohan, F.M., Brennan, J.M., Moretti, A., Tocco, G., Mule, G., Hornok, L., Giczey, G. and Tatnell, J., 2005. Predominance and association of pathogenic fungi causing Fusarium ear blight in wheat in four European countries. European Journal of Plant Pathology 112: 143-154.

Xu, X.M., Parry, D.W., Nicholson, P., Thomsett, M. a., Simpson, D., Edwards, S.G., Cooke, B.M., Doohan, F.M., Monaghan, S., Moretti, A., Tocco, G., Mule, G., Hornok, L., Béki, E., Tatnell, J. and Ritieni, A., 2008b. Within-field variability of Fusarium head blight pathogens and their associated mycotoxins. European Journal of Plant Pathology 120: 2134.

Yli-Mattila, T., Paaavanen-Huhtala, P., Parikka, P., Hietaniemi, V., Jestoi, M. and Rizzo, A., 2004. Real-time PCR detection and quantification of Fusarium poae as compared to mycotoxin production in grains in Finland. In: Canty, S.M., Boring, T., Wardwell, J. and Ward, R.W. (eds.) Proceedings of the 2nd International Symposium on Fusarium Head Blight; incorporating the 8th European Fusarium seminar. Orlando, FL, USA. East Lansing, MI: Michigan State University, pp. 422-425.

Yli-Mattila, T., Paavanen-Huhtala, S., Jestoi, M., Parikka, P., Hietaniemi, V., Gagkaeva, T., Sarlin, T., Haikara, A., Laaksonen, S. and Rizzo, A., 2008. Real-time PCR detection and quantification of Fusarium poae, F. graminearum, F. sporotrichioides and F. langsethiae in cereal grains in Finland and Russia. Archives of Phytopathology and Plant Protection 41: 243-260. 